Received: June 28, 2017

Revision received: February 25, 2018

\title{
Study on MOOC-based Blended Teaching Method in the University's Ideological \& Political Education
}

\author{
Ying Feng $^{1}$ \\ Northwest University of Political \\ Science and Law
}

\author{
Guojun $\mathrm{Qu}^{2}$ \\ Northwest University of Political \\ Science and Law
}

\begin{abstract}
The emerging MOOC has provided a new way for the university's ideological and political education. Based on the current situation analysis of the teaching methods used in college ideological and political education, this paper proposes a MOOC-based blended teaching method for college ideological and political education, then describes its advantages by use of comparative analysis, and finally analyzes its promotion and application feasibility in the university.
\end{abstract}

\section{Keywords}

Ideological and Political Education • Mooc Platform • Teaching Method • Blended Teaching

\footnotetext{
* This work is supported by the "Young Academic Innovation Team of Northwest University of Political Science and Law", Social Science Fund of Shaanxi Province: Efficiency Evaluation and Improvement of Urban Wastewater Treatment in Shaanxi Province(2015D064).

${ }^{1}$ Correspondence to: Ying Feng (PhD), Business School, Northwest University of Political Science and Law, Xi'an710122, China. Email: yingfeng8410@ 126.com

${ }^{2}$ Business School, Northwest University of Political Science and Law, Xi'an710122, China. Email: 66504673@qq.com 
The ideological and political education in the university is the major way to cultivate students' view of life, the world and value. And "duck-stuffing" type of theory teaching by ideological and political teachers has become the "bottleneck" to restrain the effect of teaching. Though in recent years many universities have conducted reform and innovation on the teaching method by adopting various methods such as video teaching, case study (Seaton, Bergner, Chuang, Mitros \& Pritchard, 2014), it’s still unsatisfactory in improving students' interest and attitude as well as the teaching effect.

With the coming of the Internet plus era, a new kind of web-based teaching-Massive Open Online Courses (MOOC) has injected new inspiration into the teaching method of college ideological and political education. Combining web-based teaching with face-to-face teaching, this teaching mode can realize the transformation from teacher-oriented to student-oriented compared to traditional teaching (Al-Atabi \& Deboer, 2014). By way of investigation analysis, this paper investigates the existing teaching method of ideological and political courses and analyzes the existing problems, then proposes the blended teaching method for these courses, and finally analyzes the promotion and application feasibility of that method in the university by way of comparative analysis combined with investigation analysis.

\section{Current situation investigation analysis of the teaching methods for college ideological and political courses}

\section{Investigation Description}

In order to better analyze the problems existing in current teaching methods for ideological and political courses, this paper uses the questionnaire to investigate and analyze the current situation of the teaching methods in those courses. The investigation evaluates the overall satisfaction of the students with the teaching method for ideological and political courses and the separate evaluation of four selected teaching methods. Totally 250 questionnaires were given out with 249 retrieved, and the final results were obtained through statistical processing.

\section{Investigation of Satisfaction with the Teaching Methods for College Ideological and Political Courses}

The Overall Evaluation of the Teaching Methods. Figure 1 shows the investigation results of teaching methods currently used in ideological and political courses. Among them, $54.57 \%$, over a half, is theoretic explanation and $10.1 \%$ is pure theory teaching, indicating that theoretic teaching is still the major kind of teaching method though there are various other methods. This will directly impact the teaching effect and quality in class.

Figure 2 shows the overall evaluation of the teaching methods in ideological and political courses made by university students. From the figure it can be seen that $54.81 \%$ is satisfied or very satisfied with current teaching methods while the non-negligible $35.99 \%$ regards them as ordinary. For the latter part there is need to analyze in detail whether the exact reason is that they possess high expectation for the teaching or that they're not interested or positive in learning. If it's the latter one, they may impact the teaching atmosphere of the whole class. 


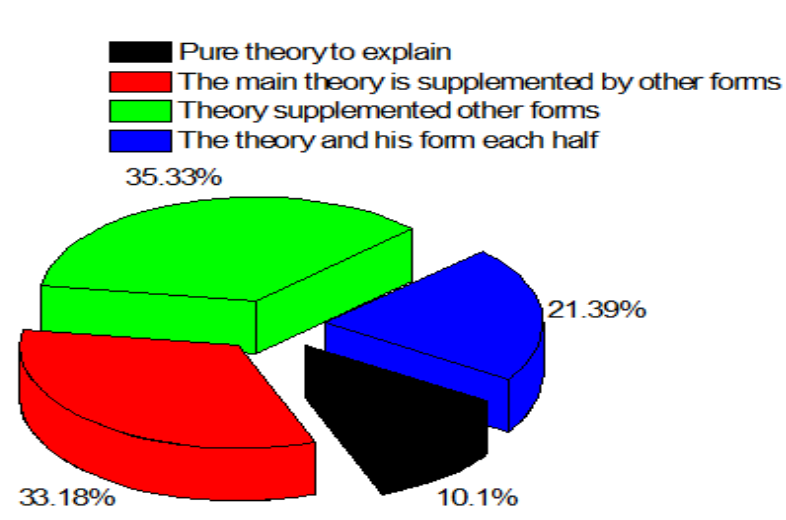

Figure 1. Teaching methods to use the situation.

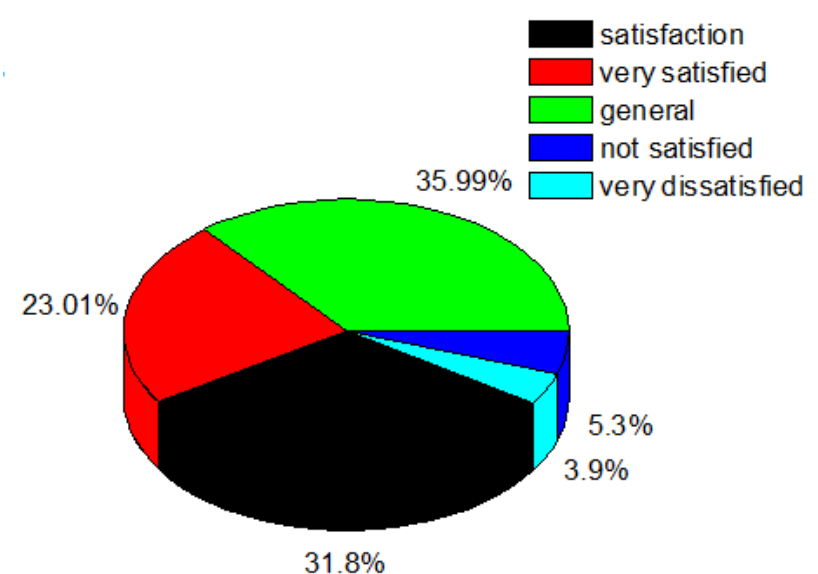

Figure 2. Teaching methods overall evaluation.

The Satisfaction with the Theoretic Teaching Method. As shown in Figure 3, in terms of traditional theoretic teaching method, only $42.26 \%$ of students like or very like them while most students have no affection for this method, showing that traditional theoretic teaching method is not welcomed by students. And the necessity investigation results of the method, as shown in Figure 4, shows that over 80\% of students regard this method as very necessary, meaning that the students can think rationally about the necessity of this method in leaning fundamental knowledge though they don't like it.

The Satisfaction with the Case Study Teaching Method. The investigation results of the satisfaction with the case study teaching method show that $42.26 \%$ of students like it very much and $29.29 \%$ of students like it while only $4.61 \%$ of students don't like it, indicating that this method is welcomed in learning ideological and political courses. Being able to inspire students' learning enthusiasm and train their comprehensive capability, it cannot enable students to thoroughly grasp the knowledge and apply it in a flexible way due to time limitation in the class. 


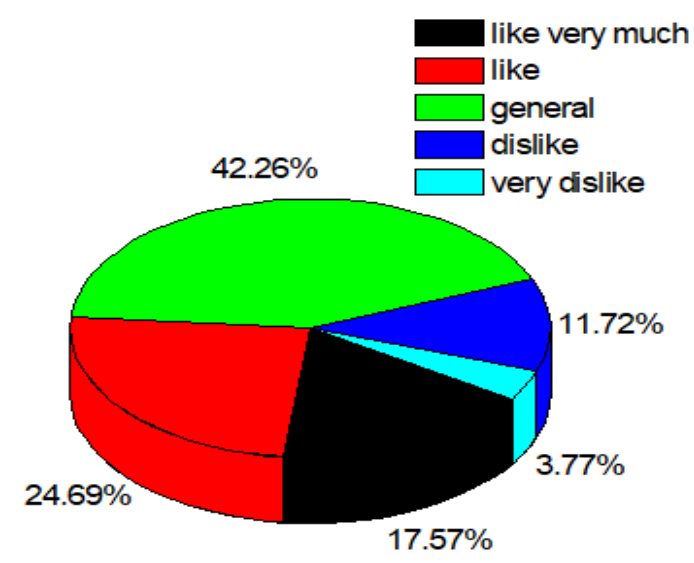

Figure 3. Theory teaching method satisfaction.

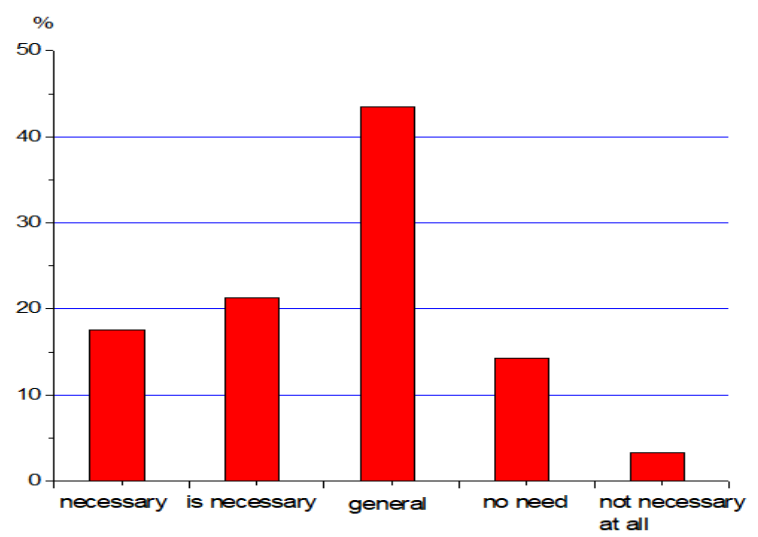

Figure 4 . Theory teaching method necessary.

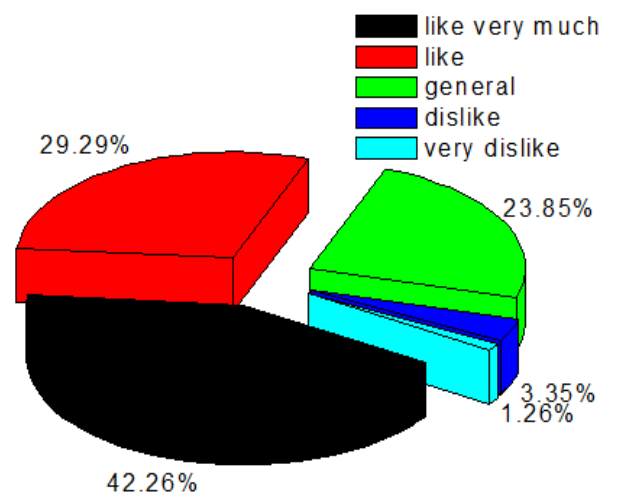

Figure 5. Case analysis satisfaction. 
The Satisfaction with the Teaching Method of Video Watching. As the investigation results in Figure 6 indicate, as high as $75.31 \%$ of students have expressed their favor of the video watching method. Compared to the first two methods, this method is more popular among college students. But due to limitation of time in the class, this method is given less time and used less frequently in actual teaching (Root Kustritz, 2014).

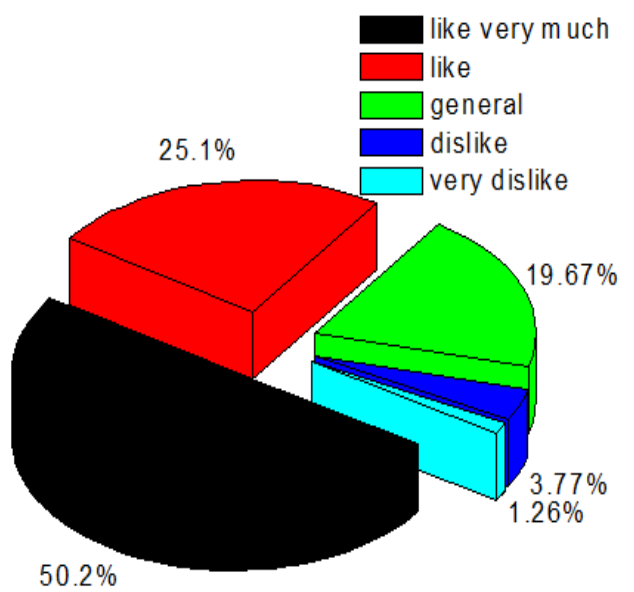

Figure 6. Video to observe the satisfaction of teaching method.

The Satisfaction with the Web-Based Teaching Method. Though used less often in ideological and political courses currently, the web-based teaching method is a trend in the future. So this paper also investigates the satisfaction with this method. As shown in Figure 7, the results show that more than a half of teachers do not use this method very often (i.e. ordinary, almost never, never). And according to the satisfaction investigation results of university students with this method as shown in Figure 8, 56.49\% of students like or very like this method while $36.82 \%$ regard it as ordinary.

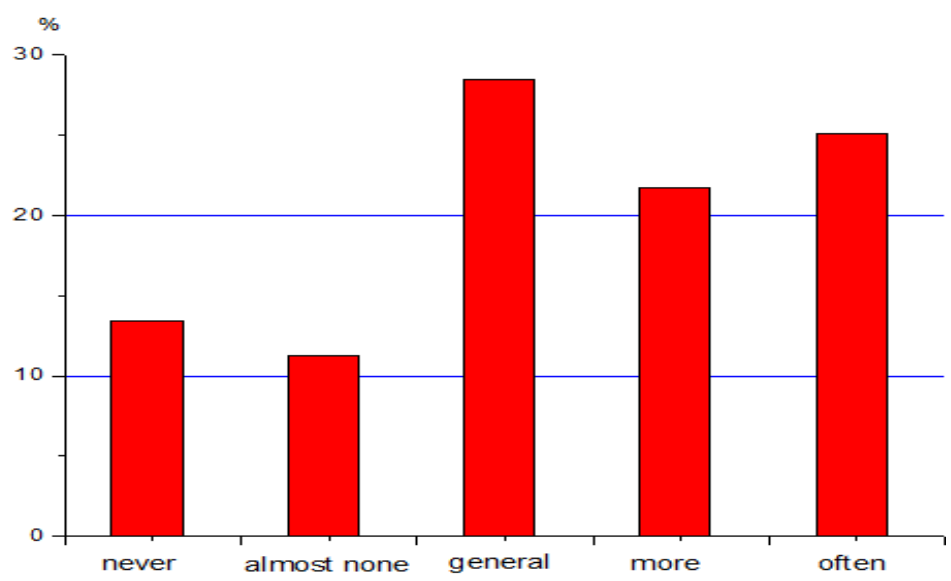

Figure 7. Network teaching method used. 


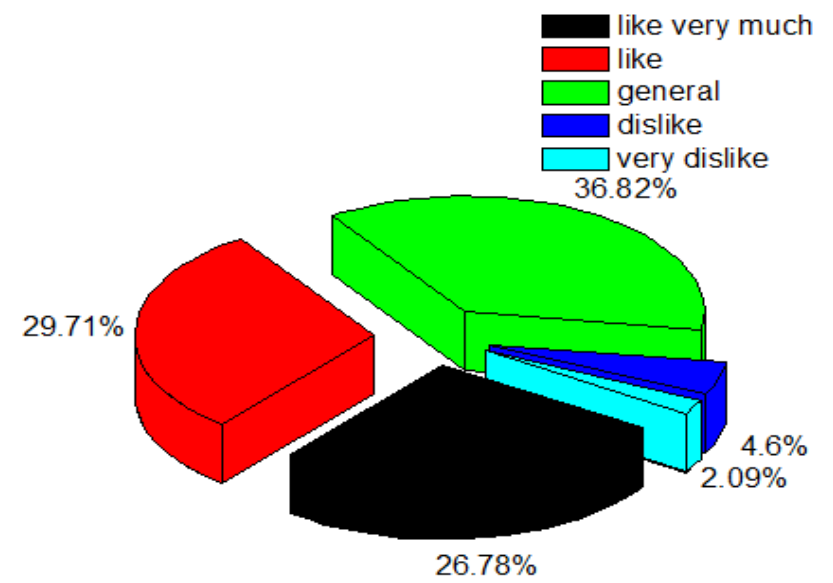

Figure 8. Network teaching method satisfaction.

To sum up, theoretic teaching method is still used the most often in teaching ideological and political courses though it is the least popular among university students. And the most popular one is the method of video watching. The web-based teaching, though used less often, can meet the demands of students in the era of Internet, so $54.69 \%$ of students like it. There exist such problems as traditional teaching evaluation methods being partial and learning style being too uniform in ideological and political courses, so it requires reform to improve the teaching quality.

\section{Study on the MOOC-based blended teaching method for college ideological \& political courses}

\section{Definition and Characteristics of MOOC}

MOOC, abbreviate for Massive Open Online Course, emerged from Europe and America in 2008. Beijing and Shanghai are the two cities where it is explored and applied the earliest in China. It has developed fast and won people's popularity because anybody can learn high-quality courses by way of online learning (Ma, Lee \& Kuo, 2013). The MOOC platform, depending on learning big data, provides a complete learning experience to learners in demand, who can choose courses and teachers according to their own demands and preference. In addition, they can learn by themselves not limited in fixed class or classroom and can communicate or interact with teachers or classmates on the interactive platform (Stokes, Towers, Jinks \& Symington, 2015).

\section{The MOOC-based Blended Teaching Method for Ideological \& Political Courses in College Education}

The MOOC-Based Blended Teaching Method. Based on MOOC, the blended teaching method combines the MOOC teaching platform developed with information technology, i.e. online teaching, and traditional class teaching, i.e. offline teaching with either indispensable (Hossain et al., 2015). Only by this way can the teachers 
transform from a "lecturer" to a "guide" and can students transform from "passive learning" to "active learning" at the same time of the high-quality resources being shared. Figure 9 is the flow chart of the MOOC-based blended teaching method (Russell, 2014).

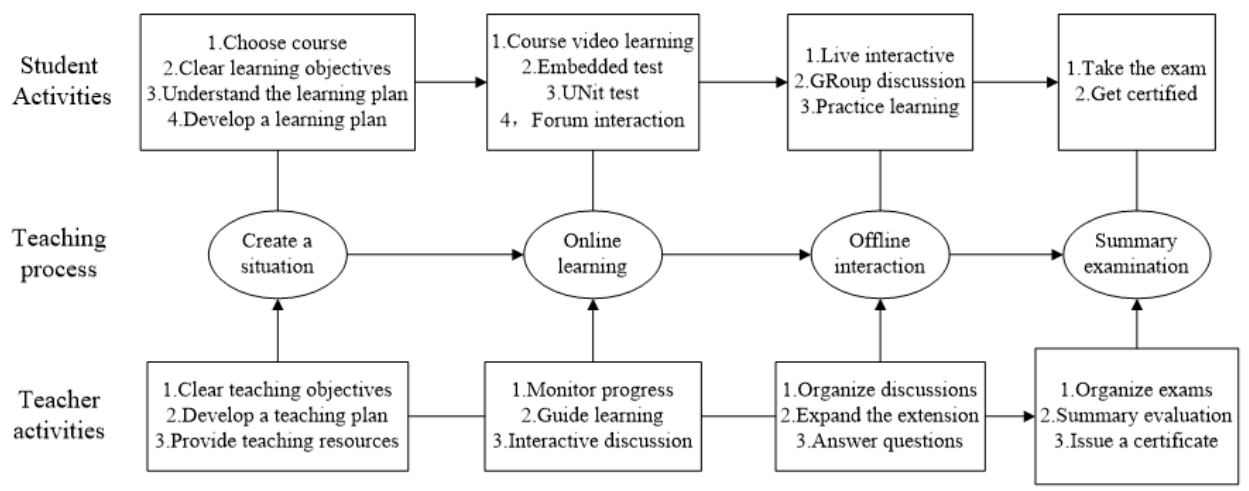

Figure 9. Based on mooc hybrid teaching flow chart.

Learning process of the blended teaching mode can be divided into 4 steps:

(1) Circumstance construction: This requires the teachers to clearly define the teaching targets, make teaching plan and reconstruct the key knowledge points aiming at building the ideological and political course system (Keith, 1998) and for the convenience of making videos. Meanwhile, it also requires the professional technical team to build and maintain the MOOC platform.

(2) Online learning: After registering on the MOOC platform, students can choose courses according to the teaching plan or by their interest and learn by themselves. During learning they can interact with teachers and other students at the discussion part on the interactive platform and finish corresponding tests ( $\mathrm{Li}, 2011)$.

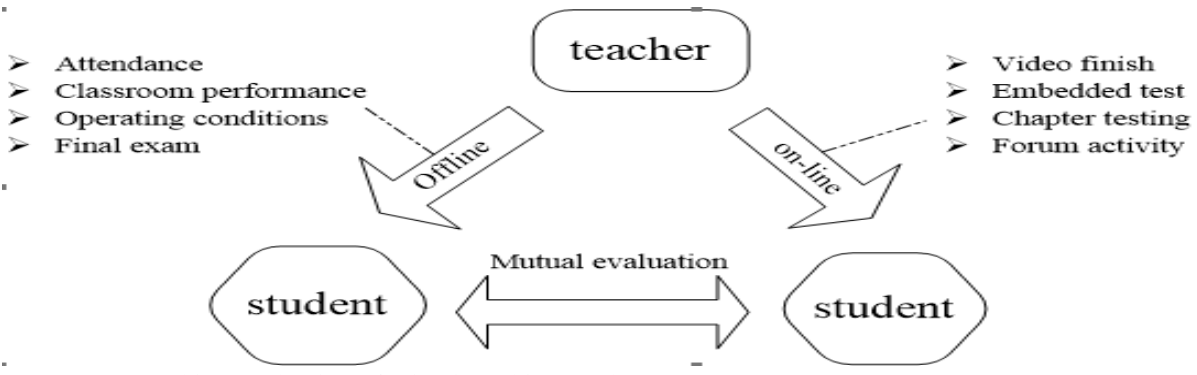

Figure 10. Teaching evaluation of mixed teaching mode.

(3) Offline interaction: The major form of interaction is the meeting course in which students can meet with teachers. In the form of group discussion, class teaching or live broadcast, it aims at motivating students to teach themselves and internalize the knowledge through guiding and FAQ by teachers.

(4) Assessment Summary: What the MOOC-based blended teaching method adopts is the comprehensive assessment (Martin, 2012). As shown in Figure 10, scores of the comprehensive assessment, different from 
traditional paper tests, compose three parts: peer-assessment, evaluation by teachers according to students' offline attendance, performance in class and final grades as well as evaluation in terms of online tests and activeness in the forum. Such evaluation mode, being able to evaluate students more comprehensively and objectively, can spur students' learning enthusiasm.

The Comparison between the MOOC-based Blended Teaching Method and Traditional Teaching Methods. As a newly-emerging teaching style, MOOC develops so fast because it owns many new characteristics and advantages compared to traditional teaching (Northcutt, Ho \& Chuang,2016) as shown in Table 1.

Table 1

MOOC Teaching and Traditional Teaching Different

\begin{tabular}{llll}
\hline \multicolumn{2}{l}{ Dimension } & \multicolumn{1}{c}{ Traditional classroom teaching } & \multicolumn{1}{c}{ MOOC teaching mode } \\
\hline \multirow{2}{*}{ teacher } & scale & a person & teamwork \\
& character & actor & director \\
& content & relatively old & rich quality \\
\multirow{2}{*}{ course } & resources & closed, & open sharing \\
& form & monotonous & complete, interactive \\
\multirow{2}{*}{ student } & quantity & less & very much \\
& learning method & passively accepted & take the initiative to explore \\
\hline
\end{tabular}

It can be described in below aspects:

(1) In terms of the teachers, they are composed of different teaching groups instead of "fighting" by themselves. Meanwhile, their role has changed from an "actor" to a "director" (Leontyev \& Baranov, 2013) and they have become the "guide" in education rather than being a "dominator".

(2) In terms of course construction, compared to traditional teaching style, the blended teaching style can provide the students with abundant high-quality teaching contents. Meanwhile, the teaching resources are open to sharing, so students can obtain more learning resources on the MOOC platform for self-learning. Moreover, this teaching style can provide students with more interaction opportunities with teachers or other student.

(3) In terms of students' learning, not confined in the classroom, the quantity of students is massive, thus providing more interaction chances to the students. Meanwhile, the learning style has transformed from "passive learning" to active exploration, which can practice students' self-learning capability to some extent.

\section{Investigation of Satisfaction with the MOOC-Based Blended Teaching Method in College Ideological \& Political Courses}

Nowadays MOOC is still not applied commonly in university's ideological and political courses. Only several universities such as the Peking University, the Tsinghua University and the Fudan University have applied the MOOC platform to their ideological and political courses or other courses by innovating a commercialized MOOC platform all by themselves or together with other companies. So this paper conducts investigation and analysis with the subject of assuming the MOOC-based blended teaching method is applied in your university (Schrader, 2004) and the results are as following. 
Knowledge about MOOC and Its Application. Figure 11 shows students' knowledge about MOOC. Among them $56.73 \%$ know nothing or almost nothing about it, and only $20.67 \%$ know a lot or quite well about it. Figure 12 shows the students' recognition for the application of the MOOC-based blended teaching style in the university. Among them $18.99 \%$ is quite in favor of that, $26.20 \%$ is in favor of that and additional $38.7 \%$ still takes wait-and-see attitude.

Though at present college students know little about MOOC due to influence from various factors, it can be known from the investigation results that they are quite interested in the application of the MOOC-based blended teaching style in ideological and political courses.

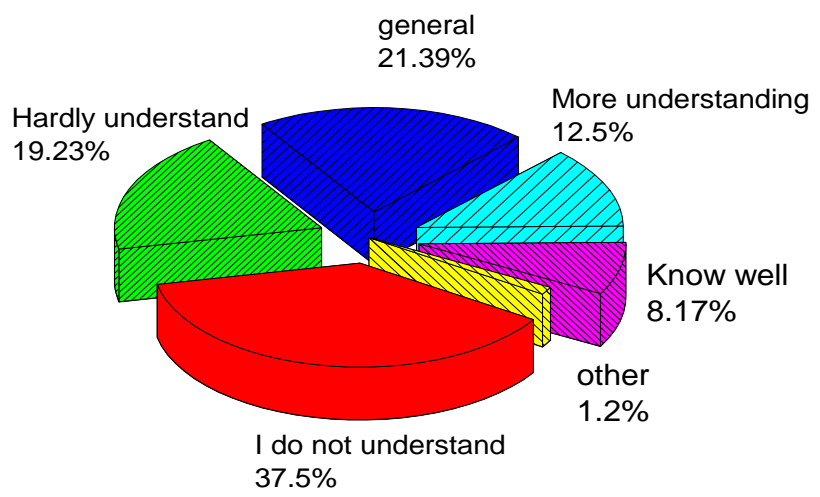

Figure 11. The level of understanding of mooc.

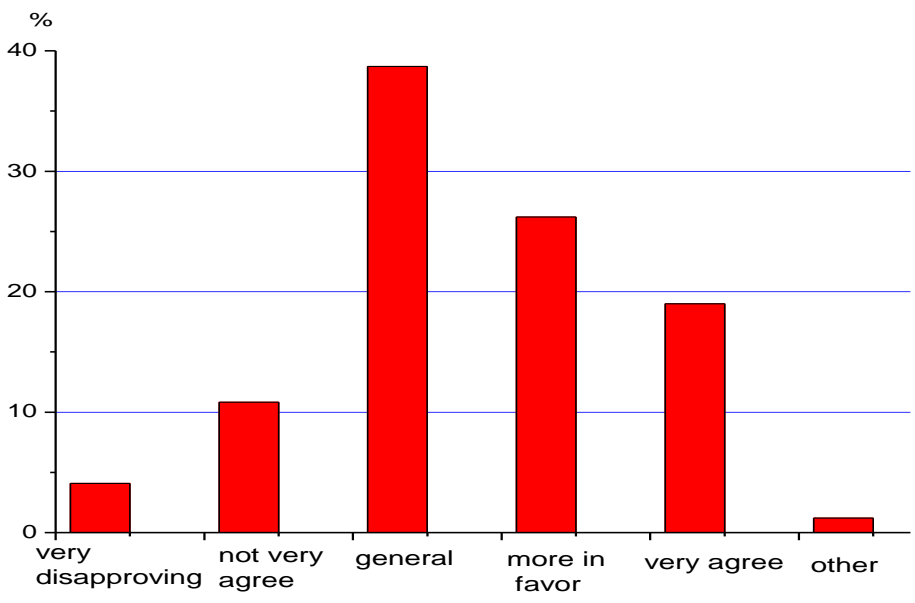

Figure 12. Acceptance of hybrid teaching methods.

\section{Recognition for the MOOC-based Blended Teaching Style in College Ideological and Political Courses.}

In the previous text it was mentioned that there are four steps for the MOOC-based blended teaching style. This 
paper subdivides and categorizes the indicators related to its last three steps of online learning, offline interaction and course summary (Berkowitz, 2006) in order to investigate the recognition for this style. The results are shown in Table 2.

Self-learning (1) is the major form and characteristic of online learning while special topic teaching (2) is the major form of offline meeting course. The interactive discussion (3) and (4) correspond respectively to the online interactive discussion of online teaching and the offline interactive discussion in offline course while process evaluation (5), (6), (7) correspond to peer-assessment, teacher assessment and online learning assessment respectively. According to the investigation results, nearly a half of students are in favor or quite in favor of this style, which indicates that university students recognize this style. In addition, $34 \%-40 \%$ of students take a wait-and-see attitude probably because the students are still not familiar with it as it is not popular at present.

Table 2

Approved the proportion of distribution

\begin{tabular}{lccccccc}
\hline \multirow{2}{*}{ Percentage\% } & $\begin{array}{c}\text { Autonomous } \\
\text { learning }\end{array}$ & $\begin{array}{c}\text { Thematic } \\
\text { teaching }\end{array}$ & \multicolumn{2}{c}{$\begin{array}{c}\text { Interactive } \\
\text { discussion }\end{array}$} & \multicolumn{3}{c}{ Process evaluation } \\
\cline { 2 - 9 } & 1 & 2 & 3 & 4 & 5 & 6 & 7 \\
\hline Approval,Very much & 48.05 & 47.7 & 49.73 & 48.53 & 47.87 & 52.44 & 49.30 \\
in favor & 38.39 & 39.8 & 36.8 & 39.25 & 40.37 & 33.88 & 38.45 \\
general & 11.17 & 10.57 & 10.82 & 9.57 & 9.13 & 11.05 & 9.84 \\
Not in favor, very & 2.39 & 1.93 & 2.65 & 2.65 & 2.63 & 2.63 & 2.41 \\
disapproving & & & & & & & \\
other
\end{tabular}

It can be deducted from the investigation results that if the MOOC-based teaching style is applied in the university, it will be able to win popularity and recognition from students.

\section{Conclusions}

Targeting at studying and exploring the teaching style in ideological and political courses, under the background of the newly-emerging web-based educational technique ---- MOOC in the Internet plus era, this paper uses the method of investigation analysis and comparative analysis to study the MOOC-based blended teaching style in the university's ideological and political courses and draw below conclusions:

(1) Based on the investigation of the existing teaching methods in the ideological and political courses, it proposes a MOOC-based blended teaching style for the ideological and political courses

(2) Through comparative analysis, it verifies the advantages of the blended teaching style for the ideological and political courses compared to traditional teaching methods.

(3) By use of investigation analysis, it analyzes the promotion and application feasibility of the MOOCbased blended teaching style in the ideological and political courses. 


\section{References}

Al-Atabi, M., Deboer, J. (2014). Teaching entrepreneurship using massive open online course (MOOC). Technovation, 34(4), 261-264. http://dx.doi. org/10.1016/j.technovation.2014.01.006

Berkowitz, M. W. (2006). Moral education and character education, their relationship and roles in citizenship education. Journal of Moral Education, 35(4), 495-518. http://dx.doi. org/ 10.1080/03057240601012204

Hossain, M. S., Shofiqul, I. M., Glinsky, J. V., Lowe, R., Lowe, T., \& Harvey, L. A. (2015). A massive open online course (mooc) can be used to teach physiotherapy students about spinal cord injuries, a randomised trial. Journal of Physiotherapy, 61(1), 21-27. http://dx.doi. org/10.1016/j.jphys.2014.09.008

Keith, C. (1998). The construction of the national curriculum, an ideological and political analysis. Research Papers in Education, 13(3), 261-276.

Leontyev, A., \& Baranov, D. (2013). Massive open online courses in chemistry, a comparative overview of platforms and features. Journal of Chemical Education, 90(11), 1533-1539.

$\mathrm{Li}$, M. (2011). Changing ideological-political orientations in Chinese moral education, some personal and professional reflections. Journal of Moral Education, 40(3), 387-395. http://dx.doi. org/10.1080/03057240.2011.596342

Ma, J. D., Lee, K. C., \& Kuo, G. M. (2013). A massive open online course on pharmacogenomics, not just disruptive innovation but a possible solution. Pharmacogenomics, 14(10), 1125-1127.

Martin, F. G. (2012). Will massive open online courses change how we teach. Communications of the Acm, 55(8), 26-28. http://dx.doi. org/10.1145/2240236.2240246

Northcutt, C. G., Ho, A. D., \& Chuang, I. L. (2016). Detecting and preventing "multiple-account" cheating in massive open online courses, Computers Education, 100, 71-80.

Root, K. M. V. (2014). Canine theriogenology for dog enthusiasts: teaching methodology and outcomes in a massive open online course (MOOC). Journal of Veterinary Medical Education, 41(1), 9-18. http://dx.doi. org/10.3138/jvme.0813-112R1

Russell, A. (2014). Research resource review, introduction to sustainability - a massive open online course (MOOC). Progress in Physical Geography, 38(6), 827-829.

Schrader, D. E. (2004). Intellectual safety, moral atmosphere, and epistemology in college classrooms. Journal of Adult Development, 11(2), 87-101. http://dx.doi. org/ 10.1023/B:JADE.0000024542.67919.55

Seaton, D. T., Bergner, Y., Chuang, I., Mitros, P., \& Pritchard, D. E. (2014). Who does what in a massive open online course. Communications of the Acm, 57(4), 58-65. http://dx.doi. org/ 10.1145/2500876

Stokes. C. W., Towers. A. C., Jinks. P. V., \& Symington, A. (2015). Discover dentistry, encouraging wider participation in dentistry using a massive open online course (MOOC). British Dental Journal, 219(2), 815. http://dx.doi. org/10.1038/sj.bdj.2015.559

Swinnerton, B. J., Morris, N. P., Hotchkiss, S., \& Pickering, J. D. (2017). The integration of an anatomy massive open online course (MOOC) into a medical anatomy curriculum. Anatomical Sciences Education, 10(1), 53. 